\title{
Sexual Abuse Identified after Suicide: Case Report
}

\author{
Kenan KAYA ${ }^{1 *}$, Ahmet HILLAL ${ }^{2}$, Eren Akgündüz ${ }^{3}$, Necmi ÇEKİN ${ }^{1,2}$ and Mete Korkut GÜLMEN ${ }^{2}$ \\ ${ }^{1}$ Ministry of Justice, Council of Forensic Medicine, Turkey \\ ${ }^{2}$ Department of Forensic Medicine, Cukurova University School of Medicine, Turkey \\ ${ }^{3}$ Ministry of Justice, Council of Forensic Medicine, Turkey \\ *Corresponding author: Kenan Kaya, Ministry of Justice, Council of Forensic Medicine, Adana, Turkey
}

Submission: 眥 February 28, 2018; Published: 眥 April 10, 2018

\begin{abstract}
Child abuse is a maltreatment of a child under the age of 18 by his or her parent, carer, someone living in their home, or someone working with children. Abuse of a child is anything that causes injury or puts the child in danger of physical injury. Child abuse can be physical, sexual or emotional. Sexual abuse has been reported to be the largest component of suicide attempts in childhood. Between 1950 and 1993, children under the age of 15 had a 4-fold increase in suicide-related deaths among causes of death. In 1994, 6 percent of deaths between 5 and 14 years of age were found to be suicidal. Case; on a 14-year-old girl's body's external examination, where dead stiffness continued and purple-colored dead stains began to appear in unprinted areas. It was recorded that the telem was viewed as a parchmented area starting from the middle line, $10 \mathrm{~cm}$ long and $1.5 \mathrm{~cm}$ wide in the thickest area. On the outer side of the left knee there was a $3 \times 2 \mathrm{~cm}$ scar tissue. It was observed that the hymen was $2 \mathrm{~cm}$ wide and had a notched structure and a partial tear at the level of 7 o'clock. There was no ecchymosis and hemorrhage around the anus and hymen. On the internal examination, a 2.5 centimeter fetus was detected in the uterus between 6-8 weeks of gestation. Only male DNA profiles were detected from the pregnancy material. Toxicological analyzes result in no detectable substance. It was determined that death was caused by mechanical asphyxia, the result of hanging. A 14-year-old girl who has been diagnosed with suicide mortality and pregnancy after autopsy will be examined in the light of literature in terms of child abuse and pregnancy.
\end{abstract}

Keyword: Death; Suicide; Sexual abuse; Child; Pregnancy

\section{Introduction}

Child abuse is the maltreatment of a child under the age of 18 by his or her parent, carer, someone living in their home, or someone working with children. Abuse of a child is anything that causes injury or puts the child in danger of physical injury. Child abuse can be physical, sexual or emotional. The World Health Organization refers to child abuse as "all of the behaviors of an adult, society or state, which harm the general values of the child's life, health, development, trust, responsibility and skills" [1].

It is stated that child abuse is an important part of sexual abuse among the causes [2]. Between 1950 and 1993, children under the age of 15 had a 4 -fold increase in suicide-related deaths among causes of death, and in 1994, 6\% of deaths between 5 and 14 years of age were suicide-related [3]. De Wilde and colleagues reported that people who had sexually abused adolescents constituted a high risk group for suicide [4]. According to a study conducted in the United States on the Youth Health Behavior, the proportion of high school students who have experienced sexual harassment has reached $20.9 \%$ in Oregon and high-risk behaviors and suicide attempts rates have been found to increase in the group of sexual exploitation, especially during adolescence [5]. In the case report, we aimed to analyze the cause of pregnancy and sexual abuse detected after the autopsy of a 14-year-old girl.

\section{Case Report}

On a 14-year-old girl's body's external examination, where dead stiffness continued and purple-colored dead stains began to appear in unprinted areas. It was recorded that the telem was viewed as a parchmented area starting from the middle line, $10 \mathrm{~cm}$ long and $1.5 \mathrm{~cm}$ wide in the thickest area. On the outer side of the left knee there was a $3 \times 2 \mathrm{~cm}$ scar tissue. It was observed that the hymen was $2 \mathrm{~cm}$ wide and had a notched structure and a partial tear at the level of 7 o'clock. Postmortem dilatation was detected in the anal examination. Ecchymosis and hemorrhage were not observed around the anus and hymen. On the internal examination, the stomach was seen as empty, and a 2.5 centimeter fetus was detected in the uterus. In the toxicological analysis of the blood taken during the autopsy, there were no foreign substances in the blood, It was determined that the fetus was between 6-8 weeks of gestation, that the pregnancy material was compatible with the male DNA profile, and that the death was caused by mechanical asphyxia the result of hanging. According to the statements taken in the forensic 
investigation; the girl was hanging in her uncle's house, the girl was already dead when the rope was cut off, the girl did not finish her primary school, the girl went to work in the cotton field 2 months ago and the girl tried to commit suicide by taking medication a month ago.

\section{Discussion}

Childhood suicides have increased in recent years. Sexual abuse of the child has an important place among causes of childhood suicide attempts. In a study conducted in 1993, 177 adolescent cases were examined and a significant relationship was found between physical or sexual abuse and suicide attempt. These cases have been reported to have recurrent suicide attempts [2]. In our case, the child had a history of suicide attempts a month ago, and the child has not been sufficiently observed, and has not been investigated for pregnancy. This shows that child abuse does not take place in the differential diagnosis. Suicide attempts affect family and society negatively; but it should not be forgotten that suicide is a call for help.

In a survey conducted by the National Society for the Prevention of Cruelty to Children (NSPCC), it was determined that the average age of sexually abused children was 10.2 and that 80 percent of these children were girls [6]. The concept of death under the age of ten is sophisticated and undefined, so there is less suicide attempt. It is believed that the developmental process of the concept of death was created at the age of 7-8 [7].

Many studies of sexual trauma show that the rate of exposure of girls to sexual assault is very common. A prevalence study has shown that 12 percent of adolescents are exposed to lifetime sexual abuse and / or assault [8]. In another literature, 76 percent of suicide attempts have been reported to occur in the home environment [9].

A child who has been sexually abused may face different psychosexual problems that affect him/her throughout his/her life. It has been reported that psychological damage caused by abuse causes the self-respect of the child to diminish in some way, and that social relations deteriorate following self-harm [10]. Kilpatrick and colleagues note that the anxieties and fears of sexual abuse (AIDS, sexually transmitted diseases, pregnancy, witnessing in court) are experienced by all victims [11]. The unacceptable nature and sudden onset of your activity lead to excessive fear, lack of control, and increased trauma response [12]. It should be kept in mind that the 14-year-old girl's pregnancy is interpreted as child abuse, and the reasons for not telling the pregnancy to the family are embarrassment, social and traditional pressure.

In such deaths, hair and similar evidence on the body and clothing in the acute process is important for the identification of the attacker. It is also suggested that (especially if genital, perianal, and anal regions have traumatic symptoms) investigate traumatic symptoms; oral, rectal, and vaginal swabs taken for DNA analysis and antigenic seminal fluid speciation, searching for vaginal and rectal impairments etc. $[13,14]$. However, in our case about the presence of a 6-8 week fetus, DNA is the most important evidence for finding the identity of the attacker.

\section{Conclusion}

According to the law, a girl aged 14 years is guilty of sexual intercourse with her own discretion. Providing adequate support for the child's protection, protecting the child from the family or community (ethical) pressures associated with possible pregnancies, and building confidence in this issue should be one of the government's most important tasks.

\section{References}

1. WHO (1999) Guidelines for medico-legal care for victims of sexual violence. Geneva, Switzerland.

2. Shaunescy K, Cohen JL, Plummer B, Bcrmaii A (1993) Suicidally in hospitalized adolescental relationship tp prior abuse. Am J Orthopsychiatry 63(1): 113-119.

3. Anonymous (1997) Rates of homicide, suicide and fire-arm related death among children 26 industrialized countries. MMWR Morb Mortal Wkly Rep 46(5): 101-105.

4. De Wilde, Kienhorst EJ, Diekstra CW, Wolters RF (1994) Social support, life events and behavioral characteristics of psychologically distressed adolescents at high risk for attempted suicide. Adolescence 29(113): 4960.

5. Nelson DE, Higginson GK, Grant Wiley WA (1994) Using the youth risk behavior survey to estimate prevalance of sexual abuse among oregon high school students. J School Health 64(10): 413-416.

6. Surrey J, Sweet C, Michaels A, Levin S (1990) Reported history of physical and sexual abuse and severity of symptomatology in women psychiatric outpatients. Am J Orthopsychiatry 60(3): 412-417.

7. Ozdogan B (1988) Child and Play Therapy. Ankara, Turkey.

8. Council on Scientific Affairs, American Medical Association (1992) Violence against women: relevance for medical practitioners. JAMA 267(23): 3184-3189.

9. Cirit H, Eğilmez A, Kültür S (1990) Investigation of psychiatric symptomatology and family characteristics in adults whoare attempting suicide. XXVI Scientific Studies of National Congress of Psychiatry and Neurological Sciences. İzmir, Turkey, pp. 547-553.

10. Zciller B (1982) Physical and psychological abused and delinquent adolescents. Child Abuse Neglet 6(2): 207.

11. Moscarello R (1990) Psycological management of victims of sexual assault. Canadian Journal of Psychiatry 35(1): 25-30.

12. Davidson JRT, Smith RD (1990) Traumatic experience in psychiatric outpatients. Journal of Traumatic Stress 3(3): 459-476.

13. Yorulmaz C, Bütün C, Dokgöz H, Citici I, Altun G (2003) Death associated with sexual abuse of children. Forensic Sci İnt 136(Suppl 1): 397-398.

14. Polat O, Yaycı N (2007) Approach to cases of death due to abuse. Child Abuse by All Dimensions. Prevention and Rehabilitation 2: 221-256. 
Creative Commons Attribution 4.0 International License

For possible submissions Click Here

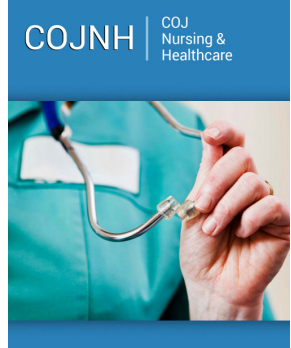

\section{COJ Nursing \& Healthcare}

\section{Benefits of Publishing with us}

- High-level peer review and editorial services

- Freely accessible online immediately upon publication

- Authors retain the copyright to their work

- Licensing it under a Creative Commons license

- Visibility through different online platforms 